\title{
Analisis Performa Take Off Engine CFM56-7B Pada Thrust Tipe 26300 Lb
}

\section{(Performance Analysis Of Take-Off Engine Cfm56-7b With Thrust Rating $26300 \mathrm{Lb}$ )}

\author{
Sri Mulyani ${ }^{1}$, Rudi Setiawan ${ }^{2}$ \\ ${ }^{1}$ Teknik Dirgantara Institut Teknologi Adisucipto, ${ }^{2}$ Akademi Angkatan Udara \\ E-mail:srimulyani042@gmail.com,rudisetiawan@aau.ac.id
}

\begin{abstract}
In some cases, if the engine performance descended, it could not be mantained as the standard perfomance requirements. According to CFM's engine manual, this case might be solved by down grading the engine configuration (TR) so that the engine still could be operated however it's performance was lower than earlier configuration. In this Final Assignment, the author discussed about comparison Take-Off performance of CFM56-7B engine between Thrust Rating configuration 26300 lbs. The performance calculation could be known by processing Test Cell Result data by the formula of Engine Shop Manual - 003. The purposes are to find the verification of both thrust rating configuration. The calculation of the take-off performance of the CFM56-7B engine with a $26300 \mathrm{lb}$ thrust rating configuration based on the formula from the Engine Shop Manual-003 Engine Acceptance Test is a $26300 \mathrm{lb}$ thrust rating configuration producing a thrust of $26920 \mathrm{lb}$. The SFC value obtained for the thrust rating is 0.3885 with an SFC margin of $-5.3 \%$ and 0.382 . The EGT generated by the engine is $905.9 C$ with an EGT margin of 17.1 C.
\end{abstract}

Keywords—take-off, engine CFM56-7B, Test Cell, Engine Shop

Abstrak - Penurunan performa engine dalam beberapa kondisi memungkinkan engine tidak dapat lagi di-maintain untuk mencapai performa yang disyaratkan. Menurut CFM masalah ini dapat diatasi dengan menurunkan versi (Thrust Rate) engine, dengan begitu engine tersebut tetap dapat beroperasi dengan standar performa yang lebih rendah dari versi awal.Dalam Tugas akhir ini penulis membahas perbandingan performa take-off engine CFM56-7B dengan konfigurasi thrust rating $26300 \mathrm{lbs}$. Perhitungan performa dilakukan dengan pengolahan data Test Cell Result menggunakan formula pada Engine Shop Manual - 003 untuk mengetahui seberapa besar perbedaan yang terjadi pada kedua konfigurasi thrust rating tersebut. Pada perhitungan performa take-off engine CFM56-7B dengan konfigurasi thrust rating $26300 \mathrm{lb}$ berdasarkan formula dari Engine Shop Manual-003 Engine Acceptance Test adalah Konfigurasi thrust rating $26300 \mathrm{lb}$ menghasilkan thrust sebesar $26920 \mathrm{lb}$. Nilai SFC yang didapatkan untuk thrust rating sebesar 0.3885 dengan SFC margin -5.3\% dan 0.382. EGT yang dihasilkan engine sebesar $905.9^{\circ} \mathrm{C}$ dan EGT margin $17.1^{\circ} \mathrm{C}$.

Kata Kunci — take-off, engine CFM56-7B, Test Cell, Engine Shop

\section{Pendahuluan}

Gase take-off merupakan fase terberat yang dialami sebuah engine pesawat udara. Pada fase ini kemampuan engine dipacu secara maksimal. Oleh karena itu, fase take-off menjadi salah satu parameter penilaian baik atau buruknya performa sebuah engine. Demi mencapai performa yang baik, pengembangan engine terus dilakukan hingga saat ini, dibuktikan dengan adanya

*Penulis Korespondensi (Sri Mulyani)

E-mail: srimulyani042@gmail.com 
berbagai manufaktur yang berlomba untuk menciptakan karya terbaik dan tercanggih untuk menarik pasar. Salah satu produsen engine tersebut adalah CFM International.Produk dari CFM International banyak digunakan untuk mendukung operasi pesawat komersial. Menurut data CFM, lebih dari 30.000 engine telah diproduksi dan dioperasikan di lebih dari 550 maskapai. Salah satu engine buatan CFM yang banyak digunakan adalah CFM56-7B dengan jumlah engine lebih dari 8000 unit yang telah dioperasikan. Engine tersebut digunakan pada pesawat Boeing B737-NG. CFM melakukan banyak pengembangan untuk engine CFM56-7B. Oleh karena itu CFM56-7B memiliki banyak varian Thrust Rating [1][2]. Banyaknya varian tersebut membuat operator memiliki banyak pilihan engine untuk mendukung misi operasi mereka, karena tiap varian memiliki karakteristik dan performa yang berbeda satu sama lain.diketahui dengan melakukan studi perhitungan serta pengujian langsung di pesawat maupun di dalam test cell[4]. Nilai specific thrust berbanding lurus dengan nilai compressor pressure ratio, tetapi berbanding terbalik dengan nilai bypass ratio[3]. Nilai specific thrust cenderung konstan pada nilai bypass ratio yang lebih tinggi, dan Thrust specific fuel consumtion akan semakin kecil pada nilai compressor pressure ratio dan bypass ratio yang lebih besar peningkatan nilai bypass ratio memberi efek positif pada peningkatan efisiensi specific fuel consumtion. Overall pressure ratio berdampak pada peningkatan nilai efisiensi dari SFC, hal tersebut dikarenakan tekanan output kompresor meningkat seiring peningkatan nilai overall pressure ratio. Peningkatan tekanan ini tentu mempengaruhi suhu pada saat masuk combution chamber yang berpengaruh pada kebutuhan fuel untuk dibakar. Sehingga semakin tinggi suhu masuk combution chamber semakin kecil kebutuhan bahan bakarnya dan semakin efisien nilai dari SFC [5].Umumnya, dengan menaikkan suhu masuk turbin, akan meningkatkan specific thrust dari engine disertai dengan peningkatan kecil dari tingkat konsumsi bahan bakar. Kombinasi rasio tekanan keseluruhan yang lebih tinggi serta specific thrust yang lebih rendah, mengarah ke specific fuel consumption yang lebih rendah [6].

\section{LANDASAN TEORI}

Siklus yang ideal untuk mesin turbin gas sederhana adalah Siklus Brayton. Siklus pada mesin turbin gas pada umumnya merupakan siklus terbuka, karena semua proses yang terjadi di dalam langsung secara terus menerus. Siklus Brayton merupakan suatu pemodelan dalam termodinamika, untuk mesin gas turbin ideal. Dalam pembahasan analisa parametrik (parametric cycle) ataupun perhitungan performa suatu mesin turbin gas pada umumnya menggunakan prinsip siklus Brayton.Proses termodinamika dalam mesin gas turbin terjadi secara kontinyu. Terjadi aliran udara yang dikompres oleh kompresor secara terus-menerus, pembakaran secara terus-menerus di dalam ruang bakar, dan tenaga yang dikeluarkan terus menerus di bagian turbin. Secara keseluruhan ada 5 siklus kerja di dalam engine turbofan, yaitu:

1. Intake - terjadi pemasukan udara dari luar ke dalam kompresor.

2. Kompresor - terjadi proses kompresi.

3. Ruang bakar - terjadi proses pembakaran.

4. Turbin - terjadi proses ekspansi.

5. Exhaust - terjadi proses pembuangan gas.

Udara luar dihisap melalui intake, kemudian dilakukan kompresi oleh blade kompresor. Udara yang dikompresi setiap stagenya akan mengalami kenaikan tekanan yang sama. Udara setelah keluar dari kompresor akan disalurkan ke ruang bakar (combustion chamber), untuk ditambahkan dengan fuel lalu kemudian diberi ignition sehingga terjadilah pembakaran. Sebelum masuk ruang bakar udara yang keluar dari kompresor akan melalui difuser untuk merubah laju aliran massa udara yang tinggi menjadi tekanan yang tinggi atau dengan kata lain merubah kecepatan menjadi tekanan.Gas hasil pembakaran dari ruang bakar akan mengalir pada jalur yang menyempit yang disebut nozzle yang berfungsi untuk merubah gas bertekanan tinggi menjadi kecepatan untuk berekspansi pada turbin secara terus menerus. Gas hasil ekspansi akan dilepas ke luar engine (atmosfer) dengan tekanan yang konstan melalui saluran exhaust. 
Berdasarkan termodinamika urutan proses yang terjadi didalam gas turbine engine dapat dinyatakan dalam suatu siklus, yang dikenal dengan siklus Brayton [7][8]. Dalam siklus tersebut terdapat empat urutan proses, sebagai berikut



Gambar 1. Siklus Brayton P-V

\section{A - B Proses kompresi:}

Pada proses ini, udara luar (atmosfer) akan dimampatkan. Hal tersebut akan menimbulkan perubahan-perubahan variabel berikut ini. Volume mengecil (V1 > V2), sedangkan tekanan membesar $(\mathrm{P} 1<\mathrm{P} 2)$. Dalam praktik, proses adiabatik tidak pernah terjadi secara sempurna pula. Namun proses adiabatik sering dipakai dalam pengkajian teoritis proses kompresi.

\section{B - C Proses Pembakaran:}

Terjadi pencampuran bahan bakar dengan udara bertekanan yang dialirkan melalui diffuser menuju ruang bakar Disini, diffuser berfungsi untuk memperlambat kecepatan aliran udara sehingga pencampuran udara dengan bahan bakar dapat sempurna. Udara primer akan masuk ke dalam zone 1, yaitu zone primer atau zone penyalaan, dimana di dalamnya terdapat penyemprot dan penyala bahan bakar. Fungsi zone penyalaan atau zone primer adalah untuk menyalakan bahan bakar dan menyediakan cukup waktu serta kondisi yang memungkinkan terjadinya proses pembakaran sempurna. Untuk menampung adanya kemungkinan pembakaran tidak sempurna, maka selanjutnya gas masuk kedalam zone 2, yaitu zone penyempurnaan pembakaran. Didalam zone 2, udara sekunder dimasukkan sebagian saja melalui lubang-lubang pada dinding tabung dalam dari ruang bakar.

Pemasukan udara sekunder diatur agar tidak menghentikan proses pembakaran, tetapi menyempurnakan pembakaran. Proses pembakaran dapat menghasilkan gas dengan temperatur tinggi, yaitu antara $2200 \mathrm{~K}-2500 \mathrm{~K}$. Namun temperatur ini terlalu tinggi bagi material ruang bakar maupun blade turbin, untuk waktu operasi yang panjang. Oleh karena itu, selubung dan bagian bagian ruang bakar harus didinginkan. Hal ini dilakukan oleh udara sekunder. Selain itu, temperatur gas pembakaran juga harus diturunkan dan hal ini pun diatasi dengan cara mencampur gas pembakaran yang panas dengan udara sekunder dengan temperature yang relatif lebih rendah.

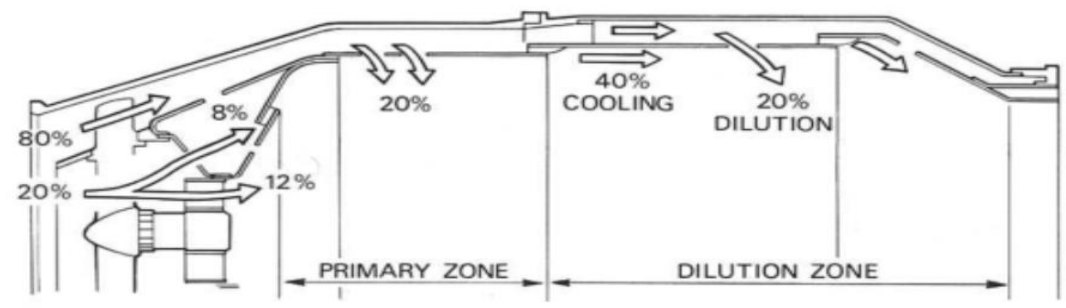

Gambar 2. Pembagian Zona pada Ruang Bakar [8] 
C - D Proses Ekspansi:

Gas hasil proses pembakaran diekspansikan melalui nozzle menuju turbin. Turbin akan merubah energi kinetik gas panas hasil pembakaran dari ruang bakar menjadi tenaga putar mekanis. Sebelum udara panas dari ruang bakar digunakan untuk memutarkan turbin, tenaga panas dan tekanannya dirubah agar mendapatkan kecepatan yang tinggi.

Untuk itu, maka bentuk dari blade yang tidak berputar atau disebut stator dibuat sedemikian rupa agar berfungsi menyerupai nozzle. Di dalam nozzle inilah kecepatan udara akan bertambah dan tekanannya akan berkurang.

D - A Proses Pembuangan:

Gas hasil pembakaran dikeluarkan melalui suatu sistem exhaust duct atau saluran pembuangan. Setelah itu gas hasil pembakaran akan mengalir keluar dari exhaust. Engine turbofan merupakan engine yang dihasilkan dari pengembangan engine turbojet [9]. Komponen turbofan sama dengan engine turbojet tetapi yang membedakan adalah engine turbofan memiliki fan (kipas) di bagian inlet. Engine jenis ini memiliki efisiensi lebih tinggi dalam segi tenaga. Karena gaya dorong yang dihasilkan bukan hanya dari pembakaran melainkan juga dari thrust dingin (cold thrust) dari aliran udara yang di-bypass. Pesawat yang memakai mesin ini rata-rata adalah pesawat penumpang seperti Boeing B737 Series dan Airbus A320 series.

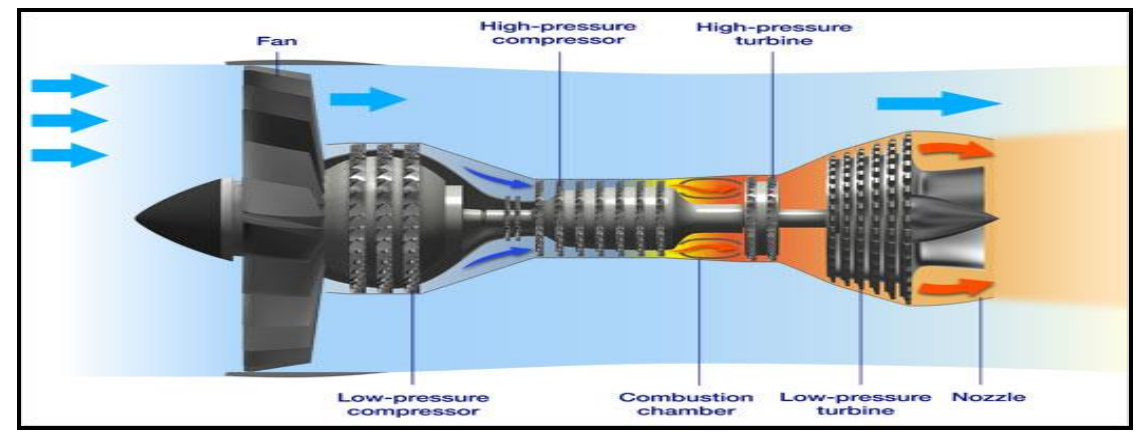

Gambar 3. Turbofan Engine[10]

Pada engine turbofan, daya poros dihasilkan untuk menggerakan fan yang bekerja dengan menghasilkan aliran udara dari bypass tersebut oleh hasil pembakaran dari jalur inti atau core engine. Perbandingan massa udara yang mengalir melalui fan terhadap massa udara yang masuk ke dalam ruang bakar disebut bypass ratio. Aliran udara melalui fan disebut aliran udara dingin dan yang melalui ruang bakar disebut aliran panas.

\section{Model YANG DiUsulKan}

\section{Metode dan Teknik Pengumpulan Data}

Pengumpulan data merupakan langkah yang amat penting dalam melakukan kajian ilmiah. Metode yang digunakan dalam pengumpulan data sangat mempengaruhi keakuratannya suatu data. Dalam penulisan penelitian ini, penulis menampilkan perumusan masalah, data dan perhitungan melalui pendekatan-pendekatan sederhana sehingga menghasilkan suatu output data yang akurat dan valid yang mudah dipahami dan dimengerti oleh pembaca. Data-data tersebut diperoleh dari hasil perhitungan dan pengamatan dari data observasi, literatur maupun wawancara yang kemudian di analisa menjadi sebuah data deskriptif.

\section{Observasi}

Studi Lapangan atau observasi, adalah metode pengumpulan data yang dilakukan dengan cara penelitian langsung. Mengumpulkan berbagai data yang dibutuhkan penulis yang bersumber langsung dari perusahaan Garuda Maintenance Facility AeroAsia (GME) yang Prosiding Seminar Nasional Sains Teknologi dan Inovasi Indonesia - Akademi Angkatan Udara Volume 3, Tahun 2021: hlm. 401-410 
melaksanakan test pada engine turbofan dengan tipe CFM56-7B dan memantau performa engine tersebut pada pesawat Boeing 737-NGs.

2. Studi Literatur

Pengumpulan data dan teori dari literatur seperti Engine Shop Manual, dan buku-buku lain yang berkaitan dan mendukung dalam melakukan analisis perbandingan performa engine CMF56-7B pada fase takeoff.

\section{Diagram Alur Penelitian}

Berikut ini adalah gambar diagram alur penelitian yang dijadikan sebagai acuan pelaksanaan penelitian

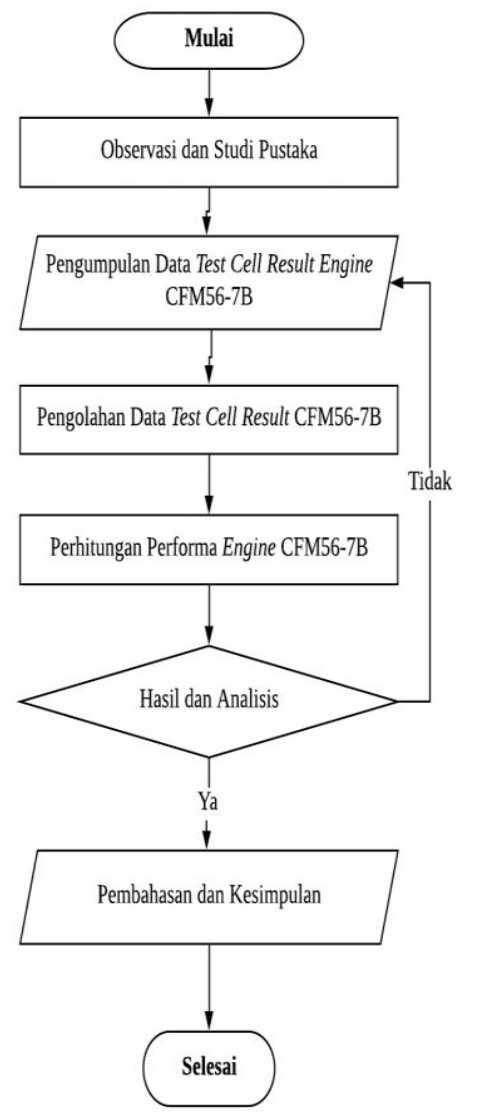

Gambar 3. Diagram Alur Penelitian

\section{IMPLEMENTASI MODEL DAN PEMBAHASAN}

\section{A. Perhitungan Performa pada Kondisi Take-off}

Dalam proses perhitungan ini, dilakukan beberapa tahapan. Tahapan pertama yang dilakukan adalah dengan mengidentifikasi parameter apa saja yang akan digunakan untuk melakukan perhitungan. Berikut adalah daftar parameter yang akan digunakan 
TABEL I

HASIL PERFORMEN TAKE OFF

\begin{tabular}{|l|l|l|l|}
\hline \hline NO & \multicolumn{1}{|c|}{ Parameter } & \multicolumn{1}{|c|}{ Value26300 Lb } & \multicolumn{1}{c|}{ Satuan } \\
\hline 1 & N1 045 & 5191 & Rpm \\
\hline 2 & N2 344 & 14501 & Rpm \\
\hline 3 & HUM & 112.6 & grains/lb \\
\hline 4 & Rel HUM & 88.9 & $\%$ \\
\hline 5 & WF Main & 10629.5 & $\mathrm{lb} / \mathrm{hr}$ \\
\hline 6 & WF Verify & 10625.7 & $\mathrm{lb} / \mathrm{hr}$ \\
\hline 7 & EGT/ T495 & 881.2 & ${ }^{\circ} \mathrm{C}$ \\
\hline 8 & T2 & 23.3 & ${ }^{\circ} \mathrm{C}$ \\
\hline 9 & T25 & 124.26 & ${ }^{\circ} \mathrm{C}$ \\
\hline 10 & T3 & 559.1 & ${ }^{\circ} \mathrm{C}$ \\
\hline 11 & PT17 & - & Psia \\
\hline 12 & BARO & 14.645 & Psia \\
\hline 13 & PT2 & 14.584 & Psia \\
\hline 14 & PS2W & 11.033 & Psia \\
\hline 15 & PT495 & 66.169 & Psia \\
\hline 16 & PS3 & 390.9 & Psia \\
\hline 17 & FN & 25940 & Lb \\
\hline 18 & LHV & 18573 & Btu/lb \\
\hline
\end{tabular}

(Sumber: Take Off Performance Result)

B. Pembahasan

a. Theta $2\left(\theta_{2}\right)$

$$
\begin{aligned}
\theta_{2} & =\frac{T 2{ }^{\circ} \mathrm{C}+273.15}{288.15} \\
\theta_{2} & =\frac{23.3^{\circ} \mathrm{C}+273.15}{288.15}=1.02867
\end{aligned}
$$

b. N1K dan N1R

$$
\begin{array}{ll}
\text { KHN } & =0.995097 \\
\text { EXPN1 } & =0.44650 \\
\text { N1K } & =\mathrm{N} 1 \text { Meas } \cdot \mathrm{KHN} 1\left(\frac{1}{\theta 2 . \text { EXPN1 }}\right) \\
\mathrm{N} 1 \mathrm{~K} & =5191 \cdot 0.995097\left(\frac{1}{1.02867 \cdot 0.44650}\right) \\
\mathrm{N} 1 \mathrm{~K} & =5101 \mathrm{rpm}
\end{array}
$$

Untuk mencari nilai N1R, perlu menghitung nilai KCONDN1 dahulu dengan cara:

$$
\begin{gathered}
\text { KCONDN1 }=(1+(\mathrm{N} 1 \mathrm{KFAC} \times \mathrm{T} . \mathrm{RISE}) \\
=(1+(-0.000131 \times 21.4)=0.997188 \\
\mathrm{N} 1 \mathrm{R}=\mathrm{N} 1 \mathrm{~K} \cdot \mathrm{KCONDN} 1 \\
\mathrm{~N} 1 \mathrm{R}=5101 \cdot 0.997188
\end{gathered}
$$




$$
\mathrm{N} 1 \mathrm{R}=5086 \mathrm{rpm}
$$

c. FNK

$\mathrm{FNK}=\frac{F N}{\delta 2} \quad$ atau $\quad \mathrm{FNK}=\mathrm{FN}$ Meas $\cdot \mathrm{KHFN} \cdot \frac{1}{\delta 2}$

Dimana:

FN Meas $=25940 \mathrm{lb}$

KHFN $=1.000322$ (berdasarkan figure 1309)

$\delta_{2}=\left(\frac{\text { PT2 in psia }}{14.696}\right)=\left(\frac{14.584}{14.696}\right)=0.992379$

Maka:

$$
\begin{aligned}
& \text { FNK }=\text { FN Meas } \cdot \text { KHFN } \cdot \frac{1}{\delta 2} \\
& \text { FNK }=25940 \cdot 1.000322 \cdot \frac{1}{0.992379} \\
& \text { FNK }=26148 \mathrm{lb}
\end{aligned}
$$

Selanjutnya, mencari data standard day dengan mengaplikasikkan test cell modifier (facility modifier correction factor) agar hasil sesuai dengan keadaan sebenarnya dengan cara sebagai berikut:

FNK1 $=$ FNK $\cdot$ FMFN $=26148 \cdot 1.022914=26747 \mathrm{lb}$

FNK $2=$ FNK $1 \cdot$ FN ADJ $=26747 \cdot 1.004672=26872 \mathrm{lb}$

FNK3 $=$ FNK2 $+\Delta \mathrm{FN}=26872+(-48)=26824 \mathrm{lb}$

$\mathrm{FN}$ ADJ $=1.004672$ (acceptance adjustment, figure 1316)

$\Delta \mathrm{FN}=48 \mathrm{lb}$

d. Fuel Flow (WF)

$$
\begin{gathered}
\text { WFK }=\text { WF Meas } \frac{1}{\delta 2} \cdot \frac{1}{\theta 2^{\mathrm{EXPWF}}} \cdot \mathrm{KHWF} \cdot \mathrm{KCONDW} \cdot \frac{\mathrm{LHV}}{18580} \\
\text { WF Meas }=\frac{10629.5+10625.7}{2}=10627.6 \mathrm{lb} / \mathrm{hr}
\end{gathered}
$$$$
\mathrm{WFK}=\mathrm{WF} \text { Meas } \frac{1}{\delta 2} \cdot \frac{1}{\theta 2^{\mathrm{EXPWF}}} \cdot \mathrm{KHWF} \cdot \mathrm{KCONDW} \cdot \frac{\mathrm{LHV}}{18580}
$$$$
\mathrm{WFK}=10627.6 \cdot \frac{1}{0.992379} \cdot \frac{1}{1.02867^{0.65}} \cdot 0.991092 \cdot 0.998476 . \frac{18619}{18580}
$$$$
\mathrm{WFK}=10406 \mathrm{lb} / \mathrm{hr}
$$$$
\text { WFK1 }=\text { WFK } \cdot \text { FMWF }
$$$$
=10406 \cdot 1.012769
$$$$
=10539 \mathrm{lb} / \mathrm{hr}
$$

WFK2 = WFK1 1 WF ADJ

$$
\begin{aligned}
& =10539 \cdot 0.99906 \\
& =10529 \mathrm{lb} / \mathrm{hr}
\end{aligned}
$$




$$
\begin{aligned}
\mathrm{WFK} 3 & =\mathrm{WFK} 2+\Delta \mathrm{WF} \\
& =10529+26.9 \\
& =10556 \mathrm{lb} / \mathrm{hr}
\end{aligned}
$$

WF ADJ $=0.99906$ (acceptance adjustment, figure 1316)

e. $\mathrm{EGT} / \mathrm{T} 495\left({ }^{\circ} \mathrm{C}\right)$

$$
\triangle \mathrm{WF}=26.9 \text { (figure 1316) }
$$

$$
\begin{aligned}
\text { EGTK }= & {\left[\left(\frac{\text { EGTM }}{\text { KSHUNT1 }}+273.15\right)\left(\frac{1}{\theta 2 \text { EXPEGT }}\right) \text { KHEGT } \cdot \text { KCONDT }-273.15\right] } \\
& \cdot \text { KSHUNT } 1+\text { KSHUNT2 }
\end{aligned}
$$

$$
\begin{aligned}
& \text { EGTK1 }=\left[\left(\frac{849-0}{1}+273.15\right) \cdot 1.006970-273.15\right] \cdot 1+0=857^{\circ} \mathrm{C} \\
& \text { EGTK2 }=\left[\left(\frac{857-0}{1}+273.15\right) \cdot 0.99637-273.15\right] \cdot 1+0=853^{\circ} \mathrm{C} \\
& \text { EGTK3 }=\left[\left(\frac{853-0}{1}+273.15\right) \cdot 0.87-273.15\right] \cdot 1+0=854^{\circ} \mathrm{C}
\end{aligned}
$$

f. $\mathrm{N} 2 \mathrm{~K}$

$$
\begin{aligned}
& \mathrm{N} 2 \mathrm{HC}=\mathrm{N} 2 \text { Meas } \cdot \mathrm{KHN} 2 \\
& \mathrm{KHN} 2=0.997506(\text { figure } 1309) \\
& \mathrm{N} 2 \text { Meas }=14501 \mathrm{rpm} \\
& \text { Maka: } \\
& \text { N2HC }=14501 \cdot 0.997506 \\
& \mathrm{~N} 2 \mathrm{HC}=14465 \mathrm{rpm}
\end{aligned}
$$

Menghitung temperatur pada 14300 physycal core speed:

1. $\mathrm{N} 2 \mathrm{HC}>14300$

$$
\begin{aligned}
& \mathrm{T} 2143=518.67^{*} \mathrm{EXP}\left(\ln \left(14300 /\left(\mathrm{N} 2 \mathrm{HC} / \theta_{2} * * \mathrm{EXPN} 2 \mathrm{G}\right)\right) / \mathrm{EXPN} 2\right) \\
& \text { EXPN2C }=0.357 \\
& \mathrm{~T} 2143=518 \cdot \mathrm{EXO}\left(\ln \left(14300 /\left(14465 / 1.02867^{0.357}\right)\right) / 0.357\right. \\
& \mathrm{T} 2143=516.7^{\circ} \mathrm{C}
\end{aligned}
$$

2. Menghitung corrected core speed:

$$
\begin{aligned}
& \mathrm{T} 2143 \leq 518.67 \\
& \mathrm{~N} 2 \mathrm{~K}=(14300 /(\mathrm{T} 2143 / 518.67) * * \mathrm{EXPN} 2 \mathrm{C}) * \mathrm{KCONDN} 2 \\
& \left.\mathrm{~N} 2 \mathrm{~K}=\left(14300 /(516.8 / 518.67)^{0.357}\right)\right) \times 1=14320 \mathrm{rpm} \\
& \mathrm{N} 2 \mathrm{~K}=\mathrm{N} 2 \mathrm{R}=14320 \mathrm{rpm} \\
& \mathrm{N} 2 \mathrm{~K} 1=\mathrm{N} 2 \mathrm{~K} \cdot \mathrm{FMN} 2 \\
& =14320 \cdot 1.001597=14342 \mathrm{rpm} \\
& \mathrm{N} 2 \mathrm{~K} 2=\mathrm{N} 2 \mathrm{~K} 1 \cdot \mathrm{N} 2 \mathrm{ADJ} \\
& =14342 \cdot 1.00080=14354 \mathrm{rpm} \\
& \mathrm{N} 2 \mathrm{~K} 3=\mathrm{N} 2 \mathrm{~K} 2+\Delta \mathrm{N} 2 \\
& \mathrm{~N} 2 \mathrm{ADJ}=1.00080 \\
& =14354+4.2=14358.2 \mathrm{rpm} \\
& \Delta \mathrm{N} 2=4.2
\end{aligned}
$$

3. $\mathrm{N} 2 / \sqrt{\theta 25}=\mathrm{N} 2$ Meas $* 1 / \sqrt{\theta 25}$

$$
\begin{aligned}
& \theta 25=\frac{T 25}{188.15}=\frac{124.26+273.15}{288.15}=1.3792 \\
& \mathrm{~N} 2 / \sqrt{\theta 25}=\frac{14501}{\sqrt{1.3792}}=12347,6505
\end{aligned}
$$


g. W2AR

$$
\begin{aligned}
& \mathrm{W} 2 \mathrm{AR}=1.32395 \cdot \mathrm{A} 2 \cdot \mathrm{KCONDA} \cdot \mathrm{BMCFWX} \cdot\left[\left(\frac{\mathrm{PS} 2 \mathrm{~W}}{\mathrm{PT} 2}\right)^{14.27}-\left(\frac{\mathrm{PS} 2 \mathrm{~W}}{\mathrm{PT} 2}\right)^{1.7135}\right]_{0.5} \\
& \mathrm{~W} 2 \mathrm{AR}=1.32395 \cdot 2622 \cdot 1 \cdot 0.979449 \cdot\left[\left(\frac{11.033}{14.584}\right)^{14.27}-\left(\frac{11.033}{14.584}\right)^{1.7135}\right]_{0.5} \\
& \mathrm{~W} 2 \mathrm{AR}=772.31 \mathrm{lb} / \mathrm{sec} \\
& \mathrm{W} 2 \mathrm{~K} 1=\mathrm{W} 2 \mathrm{AR} \cdot \mathrm{FMW} 2 \mathrm{R}=772.31 \cdot 1.008142=779 \mathrm{lb} / \mathrm{sec} \\
& \mathrm{W} 2 \mathrm{~K} 2=\mathrm{W} 2 \mathrm{~K} 1 \cdot \mathrm{W} 2 \mathrm{ADJ}=779 \cdot 1.00109=779 \mathrm{lb} / \mathrm{sec} \\
& \mathrm{W} 2 \mathrm{~K} 3=\mathrm{W} 2 \mathrm{~K} 2+\Delta \mathrm{W} 2=779+0.7=779.7 \mathrm{lb} / \mathrm{s} \\
& \text { h. Overall Compressor Pressure Ratio }(\mathrm{OCPR})
\end{aligned}
$$

$$
\mathrm{OCPR}=\frac{\mathrm{PS} 3}{\mathrm{PT} 2}=\frac{390.9}{14.584}=26.803
$$

i. Compressor Temperature Ratio (CTR)

$$
\begin{aligned}
& \text { T3 }\left({ }^{\circ} \mathrm{K}\right)=559.1+273.15=832.25^{\circ} \mathrm{K} \\
& \mathrm{T} 2\left({ }^{\circ} \mathrm{K}\right)=23.3+273.15=296.45^{\circ} \mathrm{K} \\
& \text { EXPT3 }=0.84885 \\
& \text { CTR }=\frac{\text { T3 }}{\text { T2 }}=\frac{832.25}{296.45}=2.80739
\end{aligned}
$$

j. Fan Pressure Ratio (FPR)

$$
\mathrm{FPR}=\frac{P T 17}{P T 2} \text { maka } \quad \mathrm{FPR}=\frac{0}{14.584}=0
$$

k. Menghitung nilai SFC3K

$$
\begin{aligned}
\text { SFCK3 } & =\left(\frac{\text { WFK2 }-\Delta W F F N}{\text { FNK Rated }}\right) \\
\text { SFCK } 3 & =\left(\frac{10529-311}{9608}\right)=0.3885 \mathrm{lb} / \mathrm{hr}
\end{aligned}
$$

1. Hot Day performance

$$
\begin{aligned}
\text { EGT HD }= & {\left[\left(\frac{\text { EGTK }- \text { KSHUNT2 }}{\text { KSHUNT1 }}+273.15\right) \cdot \theta 2 \cdot \text { EXPEGT }-273.15\right] } \\
& \cdot \text { KSHUNT1 }+ \text { KSHUNT2 } \\
\text { EGT HD }= & {\left[\left(\frac{849-0}{1}+273.15\right) \cdot 1.02867^{0.88504}-273.15\right] \cdot 1+0 } \\
= & 905.9^{\circ} \mathrm{C}
\end{aligned}
$$

m. SFC Margin

Engine CFM56-7B menggunakan tipe combustion chamber Single Annular Can (SAC). Maka perhitungan Specific Fuel Consumption sesuai tipe combustor chamber adalah sebagai berikut:

$$
\begin{aligned}
& \text { SFC Margin }=\left(\frac{\text { SFC REF-SFCK3 }}{\text { SFC REF }}\right) \cdot 100 \\
& \text { SFC Margin }=\left(\frac{0.369-0.3885}{0.369}\right) \cdot 100=-5.3 \%
\end{aligned}
$$

Dalam beberapa kasus, terdapat combustion chamber yang dimodifikasi menjadi tipe Double Annular Can (DAC). Maka perhitungan SFC akan berubah seperti berikut: 


$$
\operatorname{SFC} \text { Margin }(\mathrm{DAC})=\left(\frac{0.370-0.3885}{0.370}\right) \cdot 100=-5.0 \%
$$

n. Hasil perhitungan performa dengan facility modifier N1

$\begin{array}{ll}\text { Thrust Margin } & : 2.365 \% \\ \text { N1K Trim/ } \Delta \text { N1K } & : 35 \text { (Fig.1321) } \\ \text { FNDR (N1K Rate) } & : 26800 \\ \text { N2DR (N1K Rate) } & : 14380 \\ \text { EGTDR (N1K Rate) } & : 1064.96 \\ \Delta \text { FNM } & : 314 \\ \Delta \text { N2M } & : 28 \\ \Delta \text { EGTM } & : 5.68 \\ \text { FNK3M Margin } & : 306 \\ \text { FNK3M Margin \% } & : 1.16 \% \\ \text { N2K3M } & : 14330 \\ \text { EGTK3M } & : 848\end{array}$

\section{KESIMPULAN}

Hasil perhitungan performa take-off engine CFM56-7B dengan konfigurasi thrust rating $26300 \mathrm{lb}$ berdasarkan formula dari Engine Shop Manual-003 Engine Acceptance Test dengan menghasilkan thrust sebesar $26920 \mathrm{lb}$. Nilai SFC yang didapatkan untuk thrust rating sebesar 0.3885 dengan SFC margin $-5.3 \%$ dan 0.382 sedangkan EGT yang dihasilkan engine sebesar $905.9^{\circ} \mathrm{C}$ dan EGT margin $17.1{ }^{\circ} \mathrm{C}$.

\section{UCAPAN TERIMA KASIH}

Ucapan terima kasih atas terbitnya naskah ini pada Seminar Nasional Sains Teknologi dan Inovasi Indonesia 2021 sebagai bagian kolaborasi/kerjasama penelitian antara Institut Teknologi Dirgantara adengan Akademi Angkatan Udara.

\section{REFERENSI}

[1] Ackert, Shannon. 2011. "Engine Maintenance Concepts for Financiers". Aircraft Monitor.

[2] Desianto Duapadang. 2017. Analisis Perhitungan Engine Performance CFM56-7B Dengan Versi Thrust rating $26300 \mathrm{lbs}$ Pada Take-Off Position. Sekolah Tinggi Teknologi Adisutjipto. Yogyakarta

[3] Mattingly, J.D., 2005, "Elements of Gas Turbine Propulsion”. American Institute of Aeronautics and Astronautics.

[4] Sri Mulyani. 2006. Analisis Performa Engine Turbofan Pesawat Boeing 737-300, Sekolah Tinggi Teknologi Adisutjipto. Yogyakarta

[5] Roll-Royce, 1996, The Jet Engine, Roll-Royce plc. France

[6] Butterworth-Heinemann, 2014, Civil Jet Aircraft Design.

[7] Boeing. 2017. Boeing 737-600/700/800/900 Aircraft maintenance Manual.Boeing Company. Seattle, USA

[8] CFM. 2012. Course Outline CFM56-7B: Basic Engine. CFM International

[9] CFM. 2012. Course Outline CFM56-7B: General Familiarization. CFM International

[10] CFM. 2015. Service Buletin General 72-0003: Conversion of CFM56-7B Model Engine to Allowable Derivatives Model Designations. CFM International

[11] CFM. 2017, CFM56-7B Engine Shop Manual - 72-00-00-760-003-0-00-PGK-13-003-NA-0 "Engine Assembly - EngineTest 003 - Engine Accepatance Test". France 